\title{
Two novel Mg(II)-based and Zn(II)-based complexes: inhibiting growth of human liver cancer cells
}

\author{
N. Liu ${ }^{1}$, D. Ding ${ }^{2}$, L. Wang ${ }^{3}$, H. Zhao ${ }^{4}$, L. Zhu ${ }^{4}$ and X. Geng ${ }^{4}$ \\ ${ }^{1}$ Department of Critical Care Medicine, The First Affiliated Hospital of Anhui Medical University, Hefei, Anhui, China \\ ${ }^{2}$ Department of Physiology, Anhui Medical College, Hefei, Anhui, China \\ ${ }^{3}$ Department of Physiology, Basic Medical College of Anhui Medical University, Hefei, Anhui, China \\ ${ }^{4}$ Department of General Surgery, The First Affiliated Hospital of Anhui Medical University, Hefei, Anhui, China
}

\begin{abstract}
Two new $\mathrm{Mg}(\mathrm{II})$-based and $\mathrm{Zn}(\mathrm{II})$-based coordination polymers, $\left.\left\{\mathrm{Mg}_{3}(\mathrm{BTB})(\mathrm{DMA})_{4}\right](\mathrm{DMA})_{2}\right\}_{\mathrm{n}}\left(\mathbf{1}, \mathrm{H}_{3} \mathrm{BTB}=1,3,5\right.$-benzenetrisbenzoic acid, DMA=N,N-dimethylacetamide) and $\left\{\left(\mathrm{H}_{2} \mathrm{NMe}_{2}\right)_{2}\left[\mathrm{Zn}_{3}(\mathrm{BTB})_{2}(\mathrm{OH})(\mathrm{Im})\right](\mathrm{DMF})_{9}(\mathrm{MeOH})_{7}\right\}_{\mathrm{n}}(\mathbf{2}, \mathrm{Im}=\mathrm{imidazole}, \mathrm{DMF}=\mathrm{N}$, $\mathrm{N}$-dimethylformamide), have been successfully synthesized and structurally characterized under solvothermal conditions. 1 contains a linear $\left[\mathrm{Mg}_{3}(\mathrm{COO})_{6}\right]$ cluster that connected by the fully deprotonated $\mathrm{BTB}^{3-}$ ligands to give a $\boldsymbol{k g d}$-type 2D bilayer structure; 2 represents a microporous 3D pillar-layered system based on the binuclear $\mathrm{Zn}$ units and pillared Im ligands, which shows a (3,5)-connected hms topological net. In addition, in vitro anticancer activities of compounds 1 and 2 on 4 human liver cancer cells (HB611, HHCC, BEL-7405 and SMMC-7721) were determined.
\end{abstract}

Key words: Coordination polymer; Pillar-layered; Liver cancer

\section{Introduction}

Cancer is presently responsible for about $25 \%$ of deaths in developed countries and for $15 \%$ of all deaths worldwide (1). It is therefore considered one of the foremost health problems, with about 1.45 million new cancer cases expected yearly $(2,3)$. Antitumor chemotherapy is a very active field of research, and a large amount of information on the topic is generated every year $(4,5)$. However, there is a clear need for new treatments, from the medicinal chemistry and drug design point of view (6).

In recent years, aromatic multi-carboxylate acid compounds have been widely used as versatile ligands involved in various metal chelation reactions to form transition metal complexes with interesting properties in material sciences and biological systems $(7,8)$. These complexes can be easily synthesized from simple starting materials, where the metal ions, ligands, and coordination modes are the important factors for the self-assembly processes $(9,10)$. 1,3,5-benzenetrisbenzoic acid is a versatile ligand, which acts as monodentate or bridging group with end-on or end-to-end coordination mode to form complexes with interesting structures.

In this work, two new kgd-type 2D bilayer and pillarlayered coordination polymers, namely $\left\{\left[\mathrm{Mg}_{3}(\mathrm{BTB})(\mathrm{DMA})_{4}\right]\right.$ $\left.(\mathrm{DMA})_{2}\right\}_{\mathrm{n}}$ (1) and $\left\{\left(\mathrm{H}_{2} \mathrm{NMe}_{2}\right)_{2}\left[\mathrm{Zn}_{3}(\mathrm{BTB})_{2}(\mathrm{OH})(\mathrm{Im})\right](\mathrm{DMF})_{9}\right.$ $\left.(\mathrm{MeOH})_{7}\right\}_{\mathrm{n}}(2)$, were obtained (Figure 1) and their anticancer activity was evaluated.

\section{Material and Methods}

\section{Apparatus and materials}

All starting materials and reagents used in this research were obtained commercially and used without further purification. To obtain infra-red (IR) spectra $\left(400 \sim 4000 \mathrm{~cm}^{-1}\right)$, we used a Brucker Equinox-55 spectrophotometer (Bruker, Germany). Element analyses $(\mathrm{C}, \mathrm{H}$, and $\mathrm{N})$ were determined with a Vairo EL III analyzer (Elementar, Germany). Single crystal $X$-ray diffraction was carried out by an Oxford Xcalibur E diffractometer (Bruker Optics, Germany). A XT-4 micro melting apparatus (Ledon, China) was used to determine the melting points, and the thermometer remained uncorrected.

\section{Synthesis and characterization of complexes 1 and 2}

A mixture of $\mathrm{Mg}\left(\mathrm{NO}_{3}\right)_{2} \cdot 6 \mathrm{H}_{2} \mathrm{O}(25.6 \mathrm{mg}, 0.1 \mathrm{mmol})$, $\mathrm{H}_{3} \mathrm{BTB}$ (24.3 mg, $0.05 \mathrm{mmol}$ ), and DMA $/ \mathrm{H}_{2} \mathrm{O} / \mathrm{CH}_{3} \mathrm{CN}$ (V/V/ $\mathrm{V}=2 / 1 / 1,5 \mathrm{~mL}$ ) was sealed in a Teflon-lined stainlesssteel vessel $(20 \mathrm{~mL})$, and heated to $120^{\circ} \mathrm{C}$ in $12 \mathrm{~h}$, kept at $120^{\circ} \mathrm{C}$ for 3 days then slowly cooled to room temperature in $24 \mathrm{~h}$. The colorless block crystals were collected, washed with DMF, and air dried. Details are as follows: Yield: $25.3 \mathrm{mg}, 36 \%$ (based on $\mathrm{H}_{3} \mathrm{BTB}$ ligand). $\mathrm{Mp} .>300^{\circ} \mathrm{C}$. IR (KBr pellets) cm-1: 3440 (w), 2933 (w), 2433 (w), 1652 (w), 1103 (w), $930(\mathrm{~s}), 810(\mathrm{w}), 682(\mathrm{w}), 597(\mathrm{~m})$.

Correspondence: X. Geng: <xiaoping_geng666@aliyun.com> 
Elemental analysis for the framework of $1\left(\mathrm{C}_{51} \mathrm{H}_{69} \mathrm{Mg}_{3}\right.$ $\mathrm{N}_{6} \mathrm{O}_{12}$ ) was: $\mathrm{C}=59.23 ; \mathrm{H}=6.44 ; \mathrm{N}=8.29 \%$. Calculated: $\mathrm{C}=59.41 ; \mathrm{H}=6.75 ; \mathrm{N}=8.15 \%$.

A mixture of $\mathrm{Zn}\left(\mathrm{NO}_{3}\right)_{2} \cdot 6 \mathrm{H}_{2} \mathrm{O}(0.1 \mathrm{mmol}, 0.031 \mathrm{~g})$, $\mathrm{H}_{3}$ BTB (10 mg, $2.2 \mathrm{mmol}$ ) and imidazole (4.65 mg, $6.6 \mathrm{mmol})$ was added to a solution of $\mathrm{MeOH}(1 \mathrm{~mL}), \mathrm{H}_{2} \mathrm{O}$ $(2 \mathrm{~mL})$, and DMF $(2.5 \mathrm{~mL})$ in a $25 \mathrm{~mL}$ Teflon-lined stainless steel container. The container was heated at $120^{\circ} \mathrm{C}$ for $48 \mathrm{~h}$, and then cooled to room temperature at $2^{\circ} \mathrm{C} / \mathrm{min}$. The resulting material, in the form of light yellow single crystals, was washed with $\mathrm{MeOH}$ and left to air dry. Details are as follows: $\mathrm{Mp} .>300^{\circ} \mathrm{C}$. IR (KBr pellets) $\mathrm{cm}^{-1}: 3134(\mathrm{w})$,<smiles>O=C(O)c1ccc(-c2cc(-c3ccc(C(=O)O)cc3)cc(-c3ccc(C(=O)O)cc3)c2)cc1</smiles><smiles>c1c[nH]cn1</smiles>

Im

Figure 1. Schematic representation of the $\mathrm{H}_{3} \mathrm{BTB}$ and Im ligands used in this research. $2911(w), 2410(w), 1732(w), 1143(w), 976(s), 808(w)$, $689(\mathrm{w}), 590(\mathrm{~m})$. Analytical results found for compound 2 $\left(\mathrm{C}_{137} \mathrm{H}_{178} \mathrm{~N}_{21} \mathrm{O}_{36} \mathrm{Zn}_{6}\right)$ were: $\mathrm{C}=53.45 ; \mathrm{H}=5.44 ; \mathrm{N}=9.21 \%$. Calculated: $\mathrm{C}=53.30 ; \mathrm{H}=5.81 ; \mathrm{N}=9.53 \%$.

\section{Crystal structure determination}

Suitable single crystals of compounds 1 and $\mathbf{2}$ were carefully selected under optical microscope and glued on thin glass fibers. The intensity data of $\mathbf{1}$ and $\mathbf{2}$ was obtained on an Oxford Xcalibur E diffractometer. The empirical absorption corrections were applied to the data using the SADABS system. This structure was solved by direct method and refined by full-matrix least-squares method on $F^{2}$ using the SHELXS-97 program (11). All non-hydrogen atoms of 1 and $\mathbf{2}$ were refined anisotropically, and all the hydrogen atoms attached to carbon atoms were fixed at their ideal positions. Pertinent crystal data and structural refinement results for compounds $\mathbf{1}$ and $\mathbf{2}$ are summarized in Table 1.

\section{Antitumor activity}

Four human liver cancer cells (HB611, HHCC, BEL7405 and SMMC-7721) were grown in a RPMI 1460 medium supplemented with $10 \%$ fetal calf serum, $100 \mu \mathrm{g} / \mathrm{mL}$ penicillin and $100 \mu \mathrm{g} / \mathrm{mL}$ streptomycin. Cells were incubated at the temperature of $37^{\circ} \mathrm{C}$ in a moist incubator with $95 \%$ air and $5 \% \mathrm{CO}_{2}$. Cells at exponential growth were diluted to $5 \times 10^{4}$ cells $/ \mathrm{mL}$ with RPMI 1640 , and then

Table 1. Crystal data and structure refinements for compounds 1 and 2.

\begin{tabular}{|c|c|c|}
\hline & 1 & 2 \\
\hline Formula & $\mathrm{C}_{19.50} \mathrm{H}_{21} \mathrm{Mg}_{0.75} \mathrm{~N}_{1.50} \mathrm{O}_{4.5}$ & $\mathrm{C}_{99} \mathrm{H}_{71} \mathrm{~N}_{10} \mathrm{O}_{20} \mathrm{Zn}_{6}$ \\
\hline$M r$ & 366.61 & 2112.87 \\
\hline Temperature/K & $293(2)$ & $293(2)$ \\
\hline Crystal system & Monoclinic & Monoclinic \\
\hline Space group & $P 2_{1} / n$ & $P 2_{1} / c$ \\
\hline$a / \AA$ & $12.4947(4)$ & $24.3437(8)$ \\
\hline$b / \AA ̊$ & $25.7603(9)$ & $28.0222(6)$ \\
\hline$c / \AA$ & $13.7797(5)$ & $19.8450(4)$ \\
\hline$\alpha /^{\circ}$ & 90 & 90 \\
\hline$\beta 1^{\circ}$ & $99.622(3)$ & $102.182(3)$ \\
\hline$\gamma 1^{\circ}$ & 90 & 90 \\
\hline$V / \AA^{3}$ & $4372.8(3)$ & $13232.7(6)$ \\
\hline$Z$ & 8 & 4 \\
\hline$D_{\text {calc }} / \mathrm{g} \cdot \mathrm{cm}^{-3}$ & 1.114 & 1.061 \\
\hline$\mu(\mathrm{Mo} \mathrm{K} \alpha) / \mathrm{mm}^{-1}$ & 0.098 & 1.647 \\
\hline$\theta$ range $/^{\circ}$ & 2.999 to 24.999 & 3.594 to 73.853 \\
\hline Reflections collected & 15554 & 52557 \\
\hline No. unique data $[R$ (int)] & 7224 [0.0347] & $26073[0.0249]$ \\
\hline No. data with $I \geqslant 2 \sigma(I)$ & 4924 & 21300 \\
\hline$R_{1}$ & 0.0681 & 0.0430 \\
\hline$\omega R_{2}$ (all data) & 0.1939 & 0.1320 \\
\hline CCDC & 1561061 & 1561062 \\
\hline
\end{tabular}


seeded on 96 -well plates at a volume of $100 \mu \mathrm{L}$ per well, and incubated for $24 \mathrm{~h}$ at $37^{\circ} \mathrm{C}$ in $5 \% \mathrm{CO}_{2}$. After incubation of cells for up to $96 \mathrm{~h}$, the medium was removed from each cell and $150 \mu \mathrm{L}$ of MTT $(0.5 \mathrm{mg} / \mathrm{mL})$ solution, diluted 10 -fold by RPMI 1460 was subsequently added. The $\mathrm{IC}_{50}$ values were measured by depicting the ratio viability versus concentration on a logarithmic chart and obtaining the concentration where $50 \%$ of cells were inhibited. In order to get mean values, each experiment was conducted at least three times in the same way.

\section{Results and Discussion}

\section{Molecular structure}

As shown in Figure $2 \mathrm{~A}$, the asymmetric unit of $\mathbf{1}$ contains two crystallographically independent $\mathrm{Mg}(\mathrm{II})$ with $1 / 2(\mathrm{Mg} 1)$ and 1 (Mg2) occupancies, one $\mathrm{BTB}^{3-}$ ligand, two coordinated DMA and one lattice DMA molecule.
Both Mg1 and Mg2 reveal similar six-coordinated octahedral geometries. Mg1 is located at an inversion center of $(-1 / 2,0,1 / 2)$ and surrounded by six carboxylate $O$ atoms from six different BTB ligands with the $\mathrm{Mg}-\mathrm{O}$ lengths ranging from 2.021(2) to 2.037(2) $\AA$. Mg2 is coordinated by four carboxylate $\mathrm{O}$ atoms from three $\mathrm{BTB}^{3-}$ ligands and two $\mathrm{O}$ atoms from two coordinated DMA molecules with the Mg-O lengths in the range of 2.031(2)-2.203(3) $\AA$. With the aid of a bridged carboxylate, two symmetryrelated Mg2 ions and one $\mathrm{Mg} 1$ ion are held together to generate $\mathrm{a}\left[\mathrm{Mg}_{3}(\mathrm{COO})_{6}\right]$ congregation (Figure 2B). Due to the restriction of the terminal solvent molecules of $\mathrm{Mg} 2$, only a discrete $\left[\mathrm{Mg}_{3}(\mathrm{COO})_{6}\right]$ subunit is achieved. These trimeric clusters are further extended by $\mathrm{BTB}^{3-}$ ligands along the $a b$ plane to give a $2 \mathrm{D}$ bilayer pattern (Figure $2 \mathrm{C}$ ). The $\mathrm{Mg} 2 \cdots \mathrm{Mg} 2$ distance in the linearly arranged $\mathrm{Mg}_{3}$ array is about 7.199 (2) $\AA$, which is long enough to accommodate the bilayer network. These $2 \mathrm{D}$ bilayers adopt a parallel
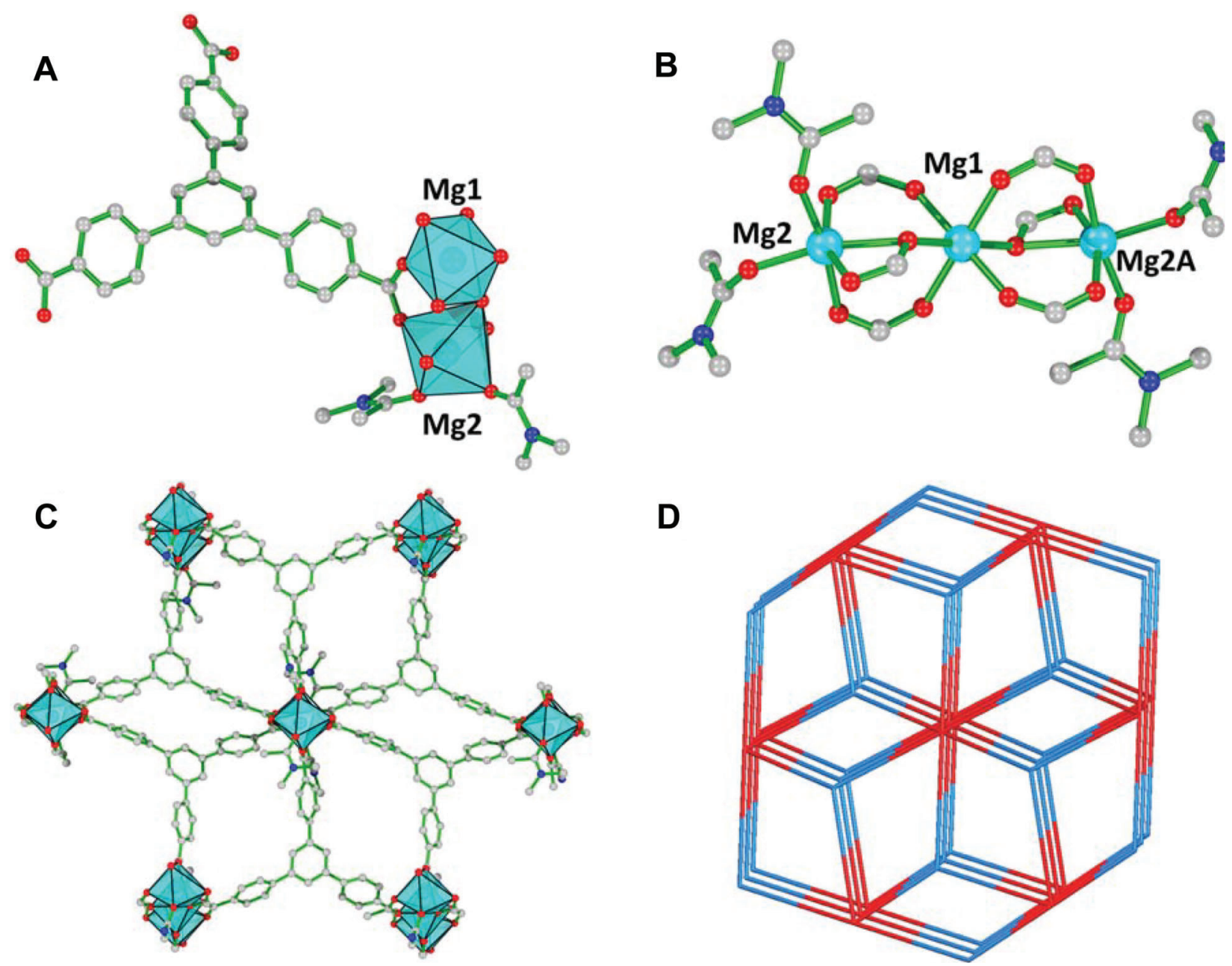

Figure 2. $A$, View of the asymmetric unit of $1 ; B$, view of the $\left[\mathrm{Mg}_{3}(\mathrm{COO})_{6}\right]$ subunit of 1 (symmetry code $\left.\mathrm{A}: 2-\mathrm{X}, 1-\mathrm{Y}, 2-\mathrm{Z}\right)$; $C$, view of the $2 \mathrm{D}$ bi-layered structure of $\mathbf{1} ; D$, the binodal $(3,6)$-connected $\boldsymbol{k g d}$ network for 1 . 
stacking arrangement to afford a 3D supramolecular architecture without classic $\mathrm{H}$-bonding or pi-pi interaction. Topologically, the $\mathrm{Mg}_{3}$ SBUs and BTB ligands can be regarded as 6- and 3-connected nodes, respectively, and afford a binodal $(3,6)$-connected $\boldsymbol{k g d}$ network with the point symbol of $\left\{4^{3}\right\}_{2}\left\{4^{6} \cdot 6^{6} \cdot 8^{3}\right\}$ (Figure 2D).

The structural analysis results indicate that compound 2 crystallizes in the monoclinic space group P2 ${ }_{1} / \mathrm{c}$, and shows a 2-fold interpenetrated network. The asymmetric unit of 2 consists of six $\mathrm{Zn}(\mathrm{II})$ ions, three $\mathrm{BTB}^{3}$-ligands, five deprotonated Im ligands, two coordinated DMF molecules, and two lattice disordered $\mathrm{H}_{2} \mathrm{NMe}_{2}$ cations. The six $\mathrm{Zn}(\mathrm{II})$ ions exhibit two different coordinating modes (Figure $3 \mathrm{~A}$ ): $\mathrm{Zn} 1, \mathrm{Zn} 2, \mathrm{Zn} 4$ and $\mathrm{Zn} 5$ atoms are four-coordinated by three $O$ atoms from three different carboxylic acid groups on the $\mathrm{BTB}^{3-}$ ligands and one $\mathrm{N}$ atom from the deprotonated Im ligand, forming a distorted tetrahedral coordination mode; atoms $\mathrm{Zn} 3$ and $\mathrm{Zn} 6$ are five-connected by one(two) $\mathrm{N}$ atom(s) from the Im ligand(s) and three(two) $\mathrm{O}$ atoms from the carboxylic acid groups, resulting in a pyrometric geometry. Zn1-Zn6, Zn2-Zn3 and Zn4-Zn5 atoms are linked by the carboxylic groups to afford the binuclear Zn secondary building units (SBUs), which are joined by the Im pillars along the $c$ axis to give rise to the 1D SBU chains (Figure 3B). In addition, the $\mathrm{BTB}^{3-}$ ligand links with the binuclear $\mathrm{Zn}$ SBUs along $b c$ plane to give the $6^{3}$ layer, and the Im ligands act as pillars between 2D sheets to form the three-dimensional (3D) framework. Due to its large solvent-accessible volume, such a framework might be large enough to accommodate another identical one to be interpenetrated, thus forming a doubly interpenetrated 3D framework with one-dimensional (1D) channel (Figure 3C). Notably, the 1D channels are decorated with Im groups, which might be favorable for the formation of a $\mathrm{H}$-bond interaction. The calculated void space per unit cell for guest-free framework is $40 \%$ as
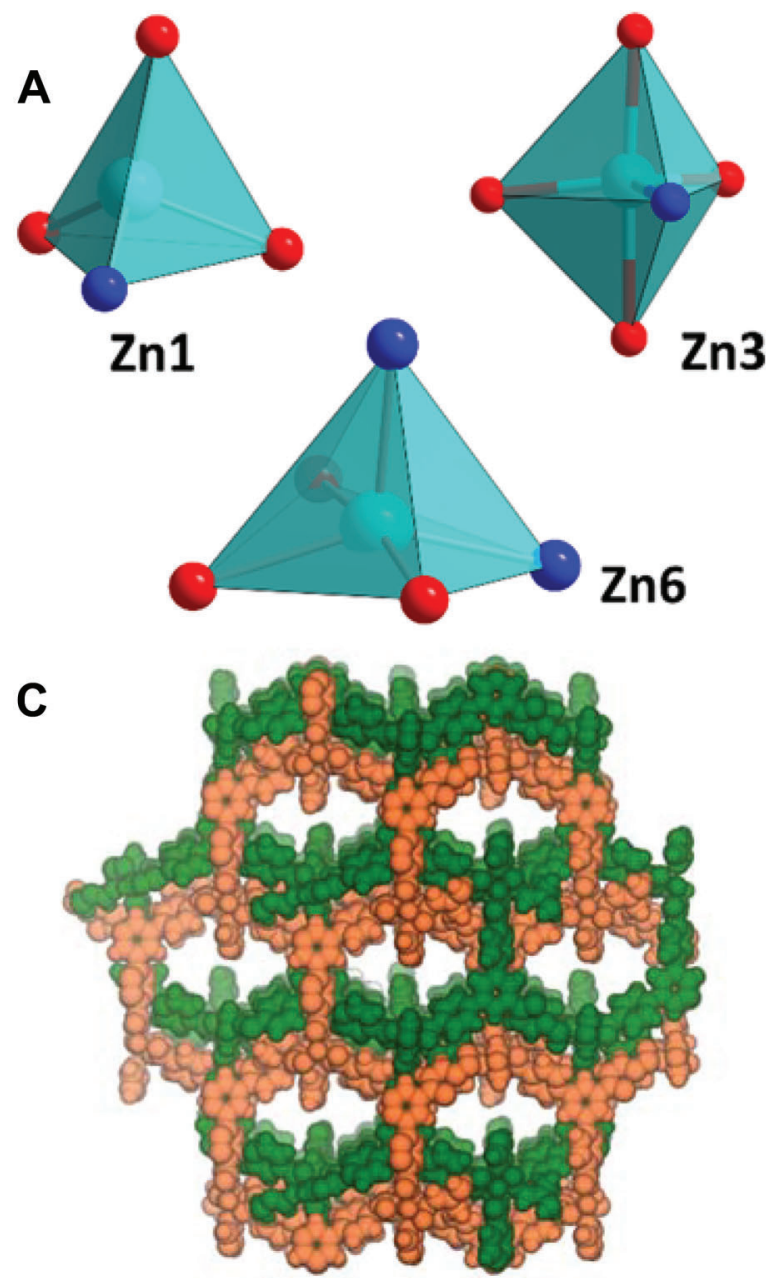
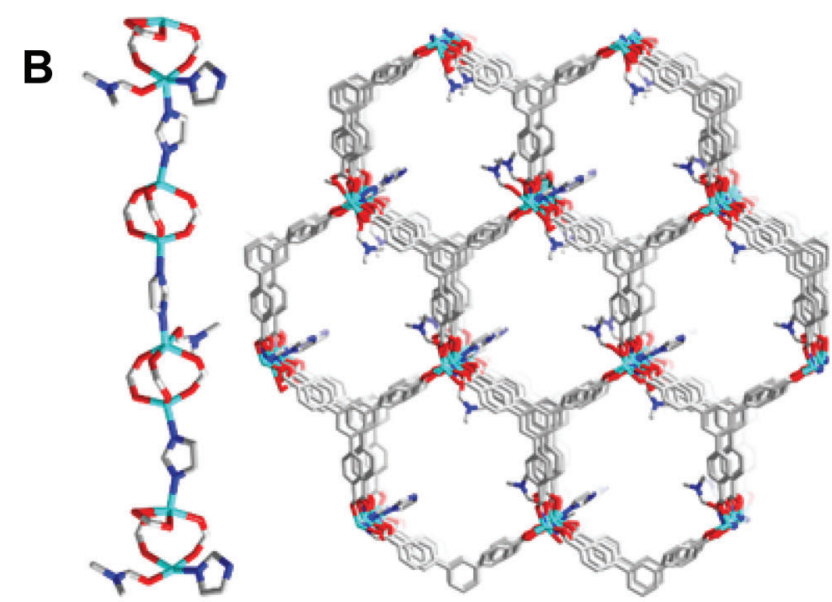

D

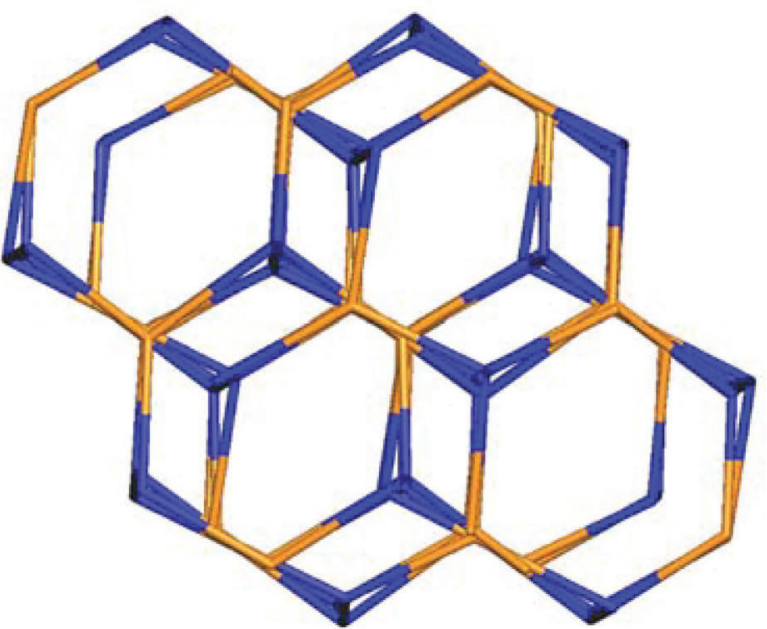

Figure 3. A, View of the coordination modes of $\mathrm{Zn}(\mathrm{II})$ ions in 2 ; $B$, view of $1 \mathrm{D}$ secondary building unit chains and the 3D pillared framework; $C$, view of the 2-fold interpenetrated 3D framework of 2; $D$, the hms-type $(3,5)$-connected topology for 2. 
Table 2. Growth inhibitory effects of 1, 2, carboplatin, $\mathrm{H}_{3} B T B$ and Im on HB611, HHCC, BEL-7405 and SMMC-7721 cancer cells.

\begin{tabular}{lrrrr}
\hline Compounds & \multicolumn{4}{c}{$\mathrm{IC}_{50}(\mu \mathrm{M})$} \\
\cline { 2 - 5 } & $\mathrm{HB} 611$ & $\mathrm{HHCC}$ & $\mathrm{BEL}-7405$ & SMMC-7721 \\
\hline $\mathrm{H}_{3}$ BTB & $>100$ & $>100$ & $>100$ & $>100$ \\
$\mathrm{Im}$ & $>100$ & $>100$ & $>100$ & $>100$ \\
$\mathbf{1}$ & 20 & 25 & 30 & 32 \\
$\mathbf{2}$ & 26 & 23 & 27 & 35 \\
Carboplatin & 25 & 30 & 25 & 40 \\
\hline
\end{tabular}

revealed by the PLATON analysis [probe radius: $1.4 \AA$ ]. From the topological point of view, the $3 \mathrm{D}$ structure of 2 can be rationalized as a 2-fold interpenetrated hmstype $(3,5)$-connected network by considering the BTB ${ }^{3-}$ ligand, binuclear $\mathrm{Zn}$ unit and the Im pillar as a 3, 5 and 2-connected node. (Figure 3D).

\section{Anticancer activity}

The cytotoxicity of the title compounds $\mathbf{1}$ and $\mathbf{2}$, reference drug carboplatin, organic ligands $\mathrm{H}_{3} \mathrm{BTB}$ and Im against HB611, HHCC, BEL-7405 and SMMC-7721 cell lines were evaluated by MTT assay, and the $\mathrm{IC}_{50}$ values derived from the experimental data are shown in Table 2. The two organic ligands were ineffective against all cell lines $\left(\mathrm{IC}_{50}>100 \mu \mathrm{M}\right)$. At this concentration, $\mathrm{H}_{3} \mathrm{BTB}$ and

\section{References}

1. Hu B, Ren J, Luo Y, Keith B, Young RM, Scholler J, et al. Augmentation of Antitumor Immunity by Human and Mouse CAR T Cells Secreting IL-18. Cell Rep 2017; 20: 30253033, doi: 10.1016/j.celrep.2017.09.002.

2. Morsy SA, Farahat AA, Nasr MNA, Tantawy AS. Synthesis, molecular modeling and anticancer activity of new coumarin containing compounds. Saudi Pharm J 2017; 25: 873-883, doi: 10.1016/j.jsps.2017.02.003.

3. Wang $Y$, Wang $Y$, Wu AA, Zhang L, Hu Z, Huang $H$, et al. New 12,8-Eudesmanolides from Eutypella sp. 1-15. $J$ Antibiot 2017; 70: 1029-1032, doi: 10.1038/ja.2017.89.

4. Zhang S, Guan J, Sun M, Zhang D, Zhang H, Sun B, et al. Self-delivering prodrug-nanoassemblies fabricated by disulfide bond bridged oleate prodrug of docetaxel for breast cancer therapy. Drug Deliv 2017; 24: 1460-1469, doi: 10.1080/10717544.2017.1381201.

5. Chi KQ, Wei ZY, Wang KS, Wu J, Chen WQ, Jin XJ, et al. Design, synthesis, and evaluation of novel ursolic acid derivatives as HIF- $1 \alpha$ inhibitors withanticancer potential. Bioorg Chem 2017; 75: 157-169, doi: 10.1016/j.bioorg.2017.09.013.

6. Kowalski S, Hać S, Wyrzykowski D, Zauszkiewicz-Pawlak A, Inkielewicz-Steppniak I. Selective cytotoxicity of vanadium complexes on human pancreatic ductal adenocarcinoma cell line by inducing necroptosis, apoptosis and mitotic
Im would exert high cytotoxicity against normal cells, thus we conclude that it did not exert inactivation towards these cell lines.

However, after the cancer cells were incubated in the presence of compounds 1 and 2 for $72 \mathrm{~h}$, the $\mathrm{IC}_{50}$ values for the compound ranged from 20 to $35 \mu \mathrm{M}$, which is similar or even lower than that of carboplatin $(25-40 \mu \mathrm{M})$, indicating that the title compounds 1 and 2 exhibited anticancer activity against these cell lines in different degrees.

According to the above-mentioned data, it can be concluded that compared with organic ligands $\mathrm{H}_{3} \mathrm{BTB}$ and $\mathrm{Im}$, the anticancer activity of compounds $\mathbf{1}$ and $\mathbf{2}$ was more effective. However, additional studies are needed to define the mechanism underlying the antitumor activity of these compounds and evaluate their efficacy in vivo. catastrophe process. Oncotarget 2017; 8: 60324-60341, doi: 10.18632/oncotarget.19454.

7. Chen J, Peng F, Zhang Y, Li B, She J, Jie X, et al. Synthesis, characterization, cellular uptake and apoptosis-inducing properties of two highly cytotoxic cyclometalated ruthenium (II) $\beta$-carboline complexes. Eur J Med Chem 2017; 140: 104-117, doi: 10.1016/j.ejmech.2017.09.007.

8. Dandash F, Léger DY, Fidanzi-Dugas C, Nasri S, Brégier F, Granet R, et al. In vitro anticancer activity of new gold(III) porphyrin complexes in colon cancer cells. J Inorg Biochem 2017; 177: 27-38, doi: 10.1016/j.jinorgbio.2017.08.024.

9. Kaulage MH, Maji B, Pasadi S, Bhattacharya S, Muniyappa K. Novel ruthenium azo-quinoline complexes with enhanced photonuclease activity in humancancer cells. Eur $J$ Med Chem 2017; 139: 1016-1029, doi: 10.1016/j.ejmech.2017. 08.059 .

10. Qi J, Zheng Y, Qian K, Tian L, Zhang GX, Cheng Z, et al. Synthesis, crystal structure and antiproliferative mechanisms of 2-acetylpyridine-thiosemicarbazones $\mathrm{Ga}$ (III) with a greater selectivity against tumor cells. J Inorg Biochem 2017; 177: 110-117, doi: 10.1016/j.jinorgbio.2017.09.012.

11. Sheldrick GM. SHELXL-97, Program for crystal structure solution and refinement. University of Göttingen: Göttingen, Germany, 1997. 